\title{
Attitudes of Students from the Faculty of Education on the Potentially Gifted Preschool Children
}

\author{
Sandra Kadum ${ }^{1}$, Emina Kopas-Vukašinović ${ }^{2}$, Ana Miljković ${ }^{2}$ \\ ${ }^{1}$ Juraj Dobrila University of Pula, Faculty of Educational Sciences, Ivana Matetića Ronjogova 1, \\ 52100 Pula, Croatia \\ ${ }^{2}$ University of Kragujevac, Faculty of Education, Milana Mijalkovića 14, 35000 Jagodina, Serbia
}

\begin{abstract}
This paper presents the results of a research aimed at examining attitudes of the students from the faculties involved in teaching (pedagogical faculties), future educators in preschool institutions, about the potential giftedness of preschool children and working with them.

The research was conducted on a sample of 174 students, future preschool educators. It was implemented at the Faculty of Educational Sciences of Pula (Croatia) and at the Faculty of Education of Jagodina (Serbia).

The results of the research confirm: that future educators are sufficiently and qualitatively educated to work with gifted children; that future educators would like to have gifted individuals in their preschool groups and would love to work with gifted children; that the relationship between gifted and other kindergarten children is harmonious and gifted children should not be separated into special kindergarten groups; gifted children are a valuable resource for the community, they do not have any difficulties in socialization and they do not waste time in a regular kindergarten, and they are not bored with such kindergarten.
\end{abstract}

DOI: $10.18421 /$ TEM104-08

https://doi.org/10.18421/TEM104-08

Corresponding author: Ana Miljković, University of Kragujevac, Faculty of Education, Milana Mijalkovića 14, 35000 Jagodina, Serbia.

Email: ana.miljkovic@pefja.kg.ac.rs

Received: 06 April 2021.

Revised: 15 September 2021.

Accepted: 22 September 2021.

Published: 26 November 2021.

(cc) BY-NC-ND (C) 2021 Sandra Kadum, Emina KopasVukašinović \& Ana Miljković; published by UIKTEN. This work is licensed under the Creative Commons AttributionNonCommercial-NoDerivs 4.0 License.

The article is published with Open Access at www.temjournal.com
Keywords - gifted children, giftedness, preschool age, students of pedagogical faculties (faculties of education), teacher-educator in preschool institutions

\section{Theoretical Approach to the Problem}

The ocuppation of the educator is becoming more and more challenging and demanding every day, because there are more and more children in preschool groups with the need for special social support. Potentially gifted children are also "concealed" among other children. The term "potential giftedness" by Kukanja Gabrijelcic and Gorela [1] states that this does not indicate with certainty that a preschooler has high potential, or the ability to achieve high achievement. Also, it can not be argued that this potential will continue to develope in the following years in appropriate manner.

We estimate the preschooler as potentially gifted, because due to rapid brain growth and development the formal intelligence testing is not conducted. Also, with pre-school children, attention is short-lived and it is difficult for them to concentrate on formal testing methods; they are simply too demanding for them. This is precisely why Vukosav and Sindik [2] point out that the use of psychological instruments is impossible in preschool-psychological practice. Specifically, it has to be taken into account that the intellectual abilities of children are multiple and they go beyond the narrow assessment offered by the IQ test [3]. Therefore, it often happens that their potentials remain unrecognized, i.e. unidentified. However, in every-day work of psychologists with the children of this age, useful data and information can be obtained for all those involved in the field of giftedness. In this way, potentially gifted children "go out of the shadows", their identification is easier and faster. Dejić, Ćebić, and Mihajlović, under the term "identification", imply "a process that seeks to single out gifted individuals in the total population in order to plan and organize a special program for them". Accordingly, Bodrić [4] states that identification of gifted children can start at an early 
preschool age, but the major part of the identification and support process takes place during the elementary school.

"Giftedness is the result of particularly favorably combined inherited traits and their interaction with the supportive and effective environment and selfactivity of a particular individual, and this effect can be recognized as a valuable and creative contribution in that area of activity". [5]

George states that "the more we learn about the characteristics of gifted and talented children, we learn that many such children have been overlooked, e.g., disabled children, children from minority groups and even some girls", as well as children with problems in behaviour and reserved / quiet ones. Considering what was said, identification should begin in early childhood. In order to detect potential giftedness, it has to come to the fore; therefore, every child in kindergarten should be viewed as potentially gifted. The development of his/her interests and opportunities should be encouraged with optimal upbringing and education. Each child shows "potential giftedness, which does not have to develop into productive giftedness, it is important that more enriching environment should be stimulated for all children" [6]. Zloković [7] states that "children (...) do not have to maintain the reached intellectual, emotional or any other developmental level, especially not in nonstimulative living conditions".

We see the child in early and pre-school education as a real fortune. However, the problem arises when we talk about the ability of the students from pedagogical faculties, future preschool educators, to identify potential children's giftedness. Namely, educators are in situations in which they face different challenges because they have to "create and implement programs that will meet the different needs of children" [8]. The development of creative potentials, which are the prerequisites for the development and identification of children's giftedness, is one of the priorities of their educational tasks in pre-school institutions, the activity of educators is the necessary condition for instigation of the development of this potential with children. Therefore, in the system of university education, it is important to empower their future educators to express, recognize and encourage their creativity when having activities with children. Studies confirm that students recognize their own expression of creativity, score high marks and see themselves in high percentage as creative. At the same time, they indicate that they do not have enough experience in creativity education [9]. When analyzing the level of professional competence in areas of pre-school (potential) giftedness [10], the results of the research point out to the problem of competence or even lack of ability of educators in the field of detection [11], recognition and identification of gifted children [12].

Analyzing the curriculum of pre-school education in Slovenia, Croatia and Serbia, Apostolović [13] notes that in Croatia and Serbia, when discussing the functions of pre-school institutions, topics are provided for the development and promotion of the gifted children. The specific detail in these programs is the inclusion of children with disabilities and the recognition and encouragement of the development of gifted children.

In order to identify the potential giftedness of the preschooler and later to develop the giftedness, it is important to develop the overall potential at an early age, which is crucial for the personal development of each child, including the potentially gifted one.

Nikčević-Milković, Jerković and Rukavina [14] state that at the beginning of the 21 st century, in the study programs for professional associates, teachers and educators, there is a need for new study programs in the field of giftedness. Vocational training in the field og giftedness has not been organized or it has been under-represented. This situation has changed in the study programs for professional associates, teachers and educators. Study programs have been introduced in the field of educational work with gifted children. It began with the assumption that an effort should be made to have educators dedicated to working with the potentially gifted child. This implies that such educators, who are interested in working with potentially gifted children, should constantly be offered a range of professional development topics in the field of giftedness.

Potentially gifted preschool children "are characterized by slightly higher social intelligence and easier and more successful adaptation to the group, they assess and meet the demands of others easily. They often have the charisma that makes them popular and beloved among children"[15]. Therefore, such a child needs an empathetic educator. According to Lepičnik-Vodopivec, Hincela and Sindik [16], the empathetic educator is open and ready to learn more about the upbringing and education of pre-school children. His/her willingness to accept the feelings, opinions and understanding of each child, and also of the potentially gifted child, is evident. Kubelka, Pelt, and Vrbanac [17] state that "working directly with preschool children is a great opportunity to monitor the learning process of young children and it allows us to discover developmental resources in these processes that we had not even thought about until yesterday". As a support to this statement, we present the results of the study with regard to spoken creativity of preschool children. It is confirmed that at the pre-school age it is advisable to 
develop their imagination and constructing skills at the level of unrealistic, to relating those phenomena which are usually non-relateble and develop originality. These children's abilities are qualitative indicators of their creativity, as well as the potential development of children's giftedness when they are older [18].

"Gifted and creative individuals have always been the bearers of civilization progress - the main development resource of society". Grandić and Letić [19] notice that developed countries in the world have realized in time that gifted and creative individuals are the potential and national wealth to be preserved. These states use the range of benefits (material support, education, and social promotion) to help gifted and creative individuals, thus helping their own state, thus contributing to its faster and better quality development. Paser and Božin [20] conclude that the gifted ones may become a social elite in case they use their giftedness for reaching certain resources that are the source of power in the society.

\section{Research Methodology}

\subsection{Subject, Aim and Tasks of the Research}

Gifted children show interest in a particular area very early, which is easily noticed by their curiosity about the problem and its solution, inexhaustible and great enthusiasm for the work, and at the same time they display great energy. This leads us to the conclusion that these children are motivated internally, intrinsically, by what they do. However, it should be noted that systematic identification and work with gifted children is still only a declared goal, with very slight, little support from the state and professional institutions. That is why the subject of this research is the question of the capability of future educators to work with preschool children.

Given the subject, the aim of the research was to examine the deliberation and attitudes of students, future educators in preschool institutions, about the potential giftedness of preschool children and working with them.

The following research objectives emerged from this goal:

1. to determine whether future educators are sufficiently and qualitatively prepared (educated) to work with gifted children;

2. to examine whether future educators in their kindergarten would like to have gifted individuals and whether they would like to work with gifted children;

3. to determine the deliberation of future educators regarding the relationship between gifted and other children in preschool institutions;
4. to examine the attitude of future educators on the socialization of gifted children in preschool institutions.

\subsection{Measuring Instrument}

The survey used the Attitude Scale, a measuring instrument put together for the purposes of this research. Two independent variables (gender and year of study of the students surveyed) were identified. A Likert-type scale, adapted to the needs of this research, was used. For each statement (hereinafter S), a response scale was offered, and the research participants selected one of the offered answers: $1=\mathrm{I}$ totaly disagree, 2 = I mostly disagree, $3=$ I do not have any specific opinion, $4=$ I mostly agree and $5=$ I totally agree.

\subsection{Sample Research}

The research sample consisted of 97 or $55.7 \%$ of the students at the Faculty of Pedagogical Sciences of the Juraj Dobrila, University of Pula (Croatia), and 77 respectively, $44.3 \%$, of the students from the Faculty of Education of the University in Kragujevac, Jagodina (Serbia). Thus, the sample consisted of a total of 174 students, future educators in preschool institutions. The sample consisted of 171 female respondents or $98.3 \%$ and 3 or $1.7 \%$ male respondents. Thirty-five or $20.1 \%$ of the survey respondents had completed grammar school (comprehensive) secondary education and the other 139 or $79.9 \%$ had completed secondary vocational education.

\subsection{Organization of Research}

The research was approved by the decision of the Commission for Ethical Evaluation of the Research at the Faculty of Pedagogical Sciences at the Juraj Dobrila University of Pula, noting that the research will be conducted both in Croatia and Serbia, at the mentioned faculties.

The ethics standards were respected throughout the study, namely the respondents were informed about the goal and the purpose of conducting the research. They were given instructions on how to fill in the questionnaire, they were guaranteed to stay anonimous, they were given the opportunity to refuse to give answers without any consequences, and it was explained to them that the data would be used solely for scientific purposes.

We would like to emphasize that the terms used in this scientific work, which have gender meanings, whether used in feminine or masculine gender, apply in the same way to respondents of feminine and masculine gender. 


\subsection{Statistical Data Processing}

We processed the obtained data with the statistical programs SPSS 20 for Windows and Excel for Windows, which were used to calculate percentage values, arithmetic means $(M)$, standard deviations $(S D)$ and Pearson correlation coefficients $(r)$.

When processing the data, we also used variance analysis to determine the $F$-values, i.e. $F$-test.

\section{Results of the Research}

Considering the research data obtained by the research and the results obtained by processing the data, we directed towards the aim of this research, to examine the attitudes of students, future educators in preschool institutions, about the potential giftedness of preschool children.

In the scientific and professional literature, we learn that professors, teachers and educators are not sufficiently trained, that they do not have the knowledge and experience to work with gifted children who compared to their peers, many things work sooner, faster and differently. Such children have better and higher achievements in what they do.That is why we offered participants the statements to help us find out about their reflections on their personal capacity to work with gifted children of preschool age. The obtained data are shown in the Table 1.

From the data in the Table 1, it can be concluded that the arithmetic means are very high, which means that the respondents mostly opted for possible answers, I mostly agree or I completely agree. Thus, in the assertion marked with Var 2 more than three quarters of respondents $(76.6 \%)$ opted for the answer I mostly agree, that is, I completely agree, whereas more than $90 \%$ of respondents $(90.6 \%)$ opted for the statement indicated with Var 4. In doing so, Kadum and Hozjan [5] point out that "it is fundamentally irrelevant who will take on a particular role in the development of a gifted child, but it is important that all roles should be fulfilled, and each of them at the most appropriate developmental moment".

Table 1. Education of Future Educators to Work with Gifted Children (Descriptive Statistics)

\begin{tabular}{|c|c|c|c|c|c|}
\hline \multirow[b]{2}{*}{ Assertion (Claim) } & \multicolumn{5}{|c|}{ Statistic indicators } \\
\hline & $N$ & Min. & Max. & $\begin{array}{c}\text { Mean } \\
(M)\end{array}$ & $\begin{array}{l}\text { Std. Deviation } \\
(S D)\end{array}$ \\
\hline $\begin{array}{l}\text { S1. Upon completion of my studies, I will be capable } \\
\text { (competent) for the identification, namely for } \\
\text { recognizing a gifted child. }\end{array}$ & 174 & 2 & 5 & 3.94 & .803 \\
\hline $\begin{array}{l}\text { S2. Upon completion of my studies, I will be capable } \\
\text { (competent) for working with gifted children. }\end{array}$ & 174 & 2 & 5 & 3.83 & .761 \\
\hline $\begin{array}{l}\text { S3. During our studies we should have a compulsory } \\
\text { study program on giftedness and gifted children. }\end{array}$ & 174 & 2 & 5 & 4.49 & .695 \\
\hline $\begin{array}{l}\text { S4. Teachers of methodologies must instruct students } \\
\text { on the importance of organized activities for } \\
\text { working with gifted children. }\end{array}$ & 174 & 2 & 5 & 4.53 & .651 \\
\hline
\end{tabular}

We were interested in whether the answers of the research participants were statistically significant according to the established assertions. For this purpose, we subjected the arithmetic means to analysis of variance and obtained that the $F$-value was 238.77. The limit value in $F$-distribution at the significance level of $5 \%$, with $3 / 170$ degrees of freedom, is 26.19. We note that our $F$-value (238.77) is significantly higher than the cut-off value (2.45), which means that it is statistically significant.

Since the $F$-value is significant, we are obliged to examine the significance of the difference between individual arithmetic means. Since claims S1 to S4 are related to the same number of subjects $(N=174)$, instead of calculating the $t$-value for each pair of variables, we calculated the critical difference of arithmetic means, i.e. critical difference of arithmetic means after $F$-value. Using the formula:

$$
C . D .=t \sqrt{\frac{2 M S_{b g}}{N_{g}}}
$$

where $\mathrm{t}$ is value, with the desired level of significance, $M S b g$ is the average sum of squares within groups of subjects-respondents and $\mathrm{Ng}$ is the number of subjects-respondents in one of the groups being compared. Number of respondents in all groups is the same, the $t$-value at the level of significance of $1 \%$ and at 170 degrees of freedom is $t$ $=2.61$, so the value of the critical difference is:

$$
\text { C.D. }=2.61 \cdot \sqrt{\frac{2 \cdot 11.30}{174}}=2.61 \cdot .36=.94 \text {. }
$$

The arithmetic mean differences between the groups are as it follows: 


$$
\begin{array}{ll}
M_{\mathrm{S} 1}-M_{\mathrm{S} 2}=.11 & M_{\mathrm{S} 3}-M_{\mathrm{S} 1}=.55 \\
M_{\mathrm{S} 4}-M_{\mathrm{S} 1}=.59 & M_{\mathrm{S} 3}-M_{\mathrm{S} 2}=.66 \\
M_{\mathrm{S} 4}-M_{\mathrm{S} 2}=.70 & M_{\mathrm{S} 4}-M_{\mathrm{S} 3}=.04
\end{array}
$$

It is observed that all differences are less than the critical difference, which means that the differences of arithmetic means are not statistically significant. We can confirm that the ability of prospective preschool teachers to work with gifted children has been demonstrated and confirmed in this sample. It has been confirmed that future educators are sufficiently and qualitatively prepared (educated) to work with gifted children.

Table 2 shows Pearson's correlation coefficients, regarding the capability of future educators to work with gifted children. It can be observed that the relationship between $\mathrm{S} 1$ and $\mathrm{S} 2$ is $r=.524$ and it is significant at the .01 level. It is also observed that the relationship between S3 and S4 is $r=.455$ and it is also significant at the .01 level. In both cases it is a moderate correlation, an essential correlation; both are positive sign correlations. The other correlation coefficients are not significant and only one of them is a negative sign.

The following set of statements that we made to the research participants were related to the work of future educators with gifted children and they contained four statements. The obtained data are shown in Table 3. It is easy to notice that the lowest arithmetic mean is 2.87 and it is related to the statement S7, which means that slightly more than

\begin{tabular}{|c|c|c|c|c|c|}
\hline & & S1 & S2 & S3 & S4 \\
\hline & $\begin{array}{l}\text { Pearson Correlation } \\
\text { Sig. (2-tailed) } \\
\text { N }\end{array}$ & $\begin{array}{c}1 \\
174\end{array}$ & & & \\
\hline $\mathrm{S} 2$ & $\begin{array}{l}\text { Pearson Correlation } \\
\text { Sig. (2-tailed) } \\
\text { N }\end{array}$ & $\begin{array}{l}.524^{* *} \\
.000 \\
174\end{array}$ & $\begin{array}{c}1 \\
174\end{array}$ & & \\
\hline S3 & $\begin{array}{l}\text { Pearson Correlation } \\
\text { Sig. (2-tailed) } \\
\text { N }\end{array}$ & $\begin{array}{l}.040 \\
.598 \\
174\end{array}$ & $\begin{array}{l}-.075 \\
.327 \\
174\end{array}$ & $\begin{array}{c}1 \\
174\end{array}$ & \\
\hline S4 & $\begin{array}{l}\text { Pearson Correlation } \\
\text { Sig. (2-tailed) } \\
\text { N }\end{array}$ & $\begin{array}{l}.070 \\
.357 \\
174 \\
\end{array}$ & $\begin{array}{l}.018 \\
.819 \\
174 \\
\end{array}$ & $\begin{array}{l}.455^{* *} \\
.000 \\
174 \\
\end{array}$ & $\begin{array}{r}1 \\
174 \\
\end{array}$ \\
\hline
\end{tabular}
$57 \%$ of the respondents according to the stated statement do not have a certain opinion.

Table 2. Correlation Matrix: Competence of Future Educators to Work with Gifted Children

Correlation is significant at the .01 level (2-tailed).

The highest arithmetic mean is bound to the claim S5 and it stands at 4.20 . Thus, $84 \%$ of the respondents mostly agree or completely agree with this statement.

To check whether the respondents' answers to this statement were statistically significant or not, we subjected the arithmetic means to the analysis of variance. We obtained an $F$-value of $F=1130.05$, which is significantly higher - more than 43 times than the cut-off value (26.19) with $3 / 170$ degrees of freedom.

Therefore, it is concluded that the respondents' answers are statistically significant, which means that future educators in their kindergarten would like to have gifted individuals and would like to work with gifted children.

Table 3. Work of Future Educators with Gifted Children (Descriptive Statistics)

\begin{tabular}{||l||c|c|c|c|c||}
\hline \multicolumn{1}{|c||}{ Assertion } & $N$ & Min. & Max. & Mean $(M)$ & $\begin{array}{c}\text { Std. Deviation } \\
(S D)\end{array}$ \\
\hline \hline $\begin{array}{l}\text { S5. I would love to have a gifted child in my } \\
\text { kindergarten. }\end{array}$ & 174 & 1 & 5 & 4.20 & .858 \\
$\begin{array}{l}\text { S6. It is much more challenging to prepare } \\
\text { activities for working with a gifted child. }\end{array}$ & 174 & 1 & 5 & 3.88 & .981 \\
$\begin{array}{l}\text { S7. I would love to work with a group where only } \\
\text { gifted children are present. }\end{array}$ & 174 & 1 & 5 & 2.87 & .985 \\
$\begin{array}{l}\text { S8. As a future educator, I will keep special notes } \\
\text { on gifted children. }\end{array}$ & 174 & 1 & 5 & 3.86 & .927 \\
\hline
\end{tabular}


Given that the F-value obtained is significant, we determined a critical differentiation: C.D. $=.42$.

Absolute values, i.e. the arithmetic mean difference modules between response groups are:

$$
\begin{array}{cc}
M_{\mathrm{S} 5}-M_{\mathrm{S} 6}=. \mathbf{3 2} & M_{\mathrm{S} 6}-M_{\mathrm{S} 7}=1.01 \\
M_{\mathrm{S} 5}-M_{\mathrm{S} 7}=1.33 & M_{\mathrm{S} 6}-M_{\mathrm{S} 8}=\mathbf{. 0 2} \\
M_{\mathrm{S} 5}-M_{\mathrm{S} 8}=. \mathbf{3 4} & M_{\mathrm{S} 7}-M_{\mathrm{S} 8}=.99
\end{array}
$$

It is observed that three differences of arithmetic means (bolded, that is, in bold letters) do not reach the critical differentiation, and therefore they are not statistically significant; the remaining three differences of arithmetic means are statistically significant.

Table 4 shows Pearson's correlation coefficients $r$, regarding the work of future educators with gifted children. It can be observed that the relation between assertions (claims) S5 and S8 is $r=.208$ and it is significant at the level .01 . It is also noteworthy that the relationship between claims $\mathrm{S} 7$ and $\mathrm{S} 8$ is significant, and it is $r=.429$ and it is significant at

\begin{tabular}{|c|c|c|c|c|}
\hline & $\bar{S} 5$ & S6 & S7 & $\overline{S \text { S8 }}$ \\
\hline $\begin{array}{l}\text { S5 Pearson Correlation } \\
\text { Sig. (2-tailed) } \\
\text { N }\end{array}$ & $\begin{array}{c}\mathbf{1} \\
174\end{array}$ & & & \\
\hline $\begin{array}{l}\text { S6 Pearson Correlation } \\
\text { Sig. (2-tailed) } \\
\text { N }\end{array}$ & $\begin{array}{l}-.068 \\
.373 \\
174\end{array}$ & $\begin{array}{c}1 \\
174\end{array}$ & & \\
\hline $\begin{array}{l}\text { S7 Pearson Correlation } \\
\text { Sig. (2-tailed) } \\
\text { N }\end{array}$ & $\begin{array}{l}.140 \\
.065 \\
174\end{array}$ & $\begin{array}{l}.019 \\
.801 \\
174\end{array}$ & $\begin{array}{c}1 \\
174\end{array}$ & \\
\hline $\begin{array}{l}\text { S8 Pearson Correlation } \\
\text { Sig. (2-tailed) } \\
\text { N }\end{array}$ & $\begin{array}{l}.208^{* *} \\
.006 \\
174\end{array}$ & $\begin{array}{l}.083 \\
.275 \\
174\end{array}$ & $\begin{array}{l}.429^{* *} \\
.000 \\
174\end{array}$ & $\begin{array}{c}1 \\
174\end{array}$ \\
\hline
\end{tabular}
the level .01. In both cases, there is a moderate and positive correlation. The other correlation coefficients are not significant and only one of them is a negative sign.

Table 4. Correlation Matrix Regarding the Work of Future Educators with Gifted Children

Correlation is significant at the .01 level (2-tailed).

The next set of statements (assertions, claims) given to the respondents reffered to gifted and other kindergarten children, is made of four statements. The data obtained are shown in Table 5. It is observed that the lowest arithmetic mean is 2.52 and it is related to the assertion (claim) S10. This means that slightly more than half of the respondents
(50.4\%) mostly disagree with this statement, i.e. they do not have specific opinion.

\begin{tabular}{|c|c|c|c|c|c|c|}
\hline \multirow{2}{*}{\multicolumn{2}{|c|}{ Assertion }} & \multicolumn{5}{|c|}{ Statistic indicators } \\
\hline & & $N$ & Min. & Max. & Mean $(M)$ & $\begin{array}{l}\text { Std. Deviation } \\
(S D)\end{array}$ \\
\hline \multirow{3}{*}{$\begin{array}{l}\text { S9 } \\
\text { S10 } \\
\text { S11 }\end{array}$} & Gifted children are neglected in kindergartens. & 174 & 1 & 5 & 3.45 & 1.040 \\
\hline & $\begin{array}{l}\text { Gifted children should go to special kindergarten } \\
\text { groups. }\end{array}$ & 174 & 1 & 5 & 2.52 & 1.106 \\
\hline & $\begin{array}{l}\text { If gifted children were separated into special } \\
\text { kindergarten groups, other children would feel } \\
\text { undervalued. }\end{array}$ & 174 & 1 & 5 & 3.75 & 1.061 \\
\hline $\mathrm{S} 12$ & $\begin{array}{l}\text { Gifted children are loved more than other children } \\
\text { in the group. }\end{array}$ & 174 & 1 & 5 & 3.44 & 1.237 \\
\hline
\end{tabular}

The highest arithmetic mean is related to the assertion S11, whose value is 3.75. This explains the fact that exactly $3 / 4$ of the survey participants, $75.0 \%$ of them mostly agree with the stated statement.

\section{Table 5. Gifted and Other Kindergarten Children (Descriptive Statistics)}

The analysis of variance revealed that the arithmetic means of these four statements are statistically significant. Namely, the $F$-value obtained is $F=380.38$ and it is almost 15 times higher than the cut-off value (26.19), with $3 / 170$ degrees of freedom, which means that the respondents' answers are statistically significant.

Therefore, the relationship between gifted and other kindergarten children is harmonious and gifted children should not be separated into special kindergarten groups. Crljen and Polić [6] speak about 
this, stating that it is important not to single out gifted children from regular kindergartens, but to equally involve all children in the education process, taking into account the needs and opportunities of each child individually. Special, additional shorter programs should be provided for particularly gifted individuals.

Since the $F$-value is significant, we have determined the critical difference and it amounts to C.D. $=.63$.
The absolute values (modules) of the difference of arithmetic means between groups are:

$$
\begin{array}{ll}
M_{\mathrm{S} 9}-M_{\mathrm{S} 10}=.93 & M_{\mathrm{S} 10}-M_{\mathrm{S} 11}=1.23 \\
M_{\mathrm{S} 9}-M_{\mathrm{S} 11}=. \mathbf{3 0} & M_{\mathrm{S} 10}-M_{\mathrm{S} 12}=.92 \\
M_{\mathrm{S} 9}-M_{\mathrm{S} 12}=. \mathbf{0 1} & M_{\mathrm{S} 11}-M_{\mathrm{S} 12}=. \mathbf{3 1}
\end{array}
$$

It can be seen from the overview that three differences of arithmetic means do not reach the critical difference, which means that they are not statistically significant; the remaining three

\begin{tabular}{|c|c|c|c|c|c|}
\hline & & S9 & S10 & S11 & S12 \\
\hline S9 & $\begin{array}{l}\text { Pearson Correlation } \\
\text { Sig. (2-tailed) } \\
\text { N }\end{array}$ & $\begin{array}{c}1 \\
174\end{array}$ & & & \\
\hline S10 & $\begin{array}{l}\text { Pearson Correlation } \\
\text { Sig. (2-tailed) } \\
\text { N }\end{array}$ & $\begin{array}{l}.212^{* *} \\
.005 \\
174\end{array}$ & $\begin{array}{c}1 \\
174\end{array}$ & & \\
\hline S11 & $\begin{array}{l}\text { Pearson Correlation } \\
\text { Sig. (2-tailed) } \\
\text { N }\end{array}$ & $\begin{array}{l}-.005 \\
.944 \\
174\end{array}$ & $\begin{array}{r}-.336^{* *} \\
.000 \\
174\end{array}$ & $\begin{array}{c}1 \\
174\end{array}$ & \\
\hline S12 & $\begin{array}{l}\text { Pearson Correlation } \\
\text { Sig. (2-tailed) } \\
\text { N }\end{array}$ & $\begin{array}{l}-.170 \\
.025 \\
174 \\
\end{array}$ & $\begin{array}{l}.030 \\
.691 \\
174 \\
\end{array}$ & $\begin{array}{l}.068 \\
.372 \\
174 \\
\end{array}$ & 174 \\
\hline
\end{tabular}
arithmetic mean differences between the groups are statistically significant.

Table 6. Correlation Matrix Set of Claims on Gifted and Other Children in a Kindergarten Group

Correlation is significant at the .01 level (2-tailed).

Table 6 shows Pearson's correlation coefficients $r$, regarding the set of assertions on gifted and other children in the nursery group. It is observed that the relationship between claims $\mathrm{S} 9$ and $\mathrm{S} 10$ is significant at the .01 level and it is $r=.212$. The relationship between S10 and S11 is negative, and it is $r=-.336$, and it is significant at the level .01.

In both cases it is a moderate, in the first case a positive and in the second case a negative correlation.
The other correlation coefficients are not significant, two of which are of positive and two are of negative sign.

With the next set, which also contains four statements (assertions), we wanted to determine what the research participants' opinion on gifted children and their socialization are, and regarding their stay in

\begin{tabular}{|c|c|c|c|c|c|c|}
\hline \multirow{2}{*}{\multicolumn{2}{|c|}{ Assertion }} & \multicolumn{5}{|c|}{ Statistic indicators } \\
\hline & & $N$ & Min. & Max. & Mean $(M)$ & $\begin{array}{l}\text { Std. Deviation } \\
(S D)\end{array}$ \\
\hline S13 & $\begin{array}{l}\text { A gifted child has difficulty socializing } \\
\text { with other children. }\end{array}$ & 174 & 1 & 5 & 2.89 & 1.019 \\
\hline S14 & $\begin{array}{l}\text { Gifted children waste time in regular } \\
\text { kindergarten groups. }\end{array}$ & 174 & 1 & 5 & 2.26 & 1.007 \\
\hline $\mathrm{S} 15$ & $\begin{array}{l}\text { In classic kindergarten mode, a gifted child } \\
\text { is bored. }\end{array}$ & 174 & 1 & 5 & 3.49 & .996 \\
\hline S16 & $\begin{array}{l}\text { Gifted children are a valuable resource for } \\
\text { the community. }\end{array}$ & 174 & 2 & 5 & 4.36 & .768 \\
\hline
\end{tabular}
regular kindergarten groups. The results of the statement are shown in Table 7.

Table 7. Gifted Child Socialization (Descriptive Statistics)

It is apparent from the Table 7 that the dominant arithmetic mean is that which binds to the assertion S16 and it is 4.36 . This tells us that $87.2 \%$ of the respondents mostly agree or completely agree. The lowest arithmetic mean is related to the assertion S14 and its value is 2.26 , which means that almost half of the respondents $(45.2 \%)$ completely disagree with the stated statement or mostly disagree.

In order to determine whether the respondents' answers in this statement of claims are statistically 
significant, we subjected the arithmetic means to the analysis of the variance and obtained the $F$-value is 552.33. As the $F$-value obtained is very high in comparison to the limit value (26.19) with $3 / 170$ degrees of freedom, it follows that the respondents' answers are statistically significant. This confirms that gifted children are a valuable resource for the community, that they do not have any difficulties in socialization, that they do not waste time in regular kindergarten groups, and that they are not bored in such an environment. In the literature, the authors state that children will remember for a long time after transferring from preschool institution to school, the messages on their giftedness, hoping that they will follow them in the further process of education [17].

Since the $F$-value is significant, we have determined the critical difference and it amounts to C.D. $=.52$.

The absolute values (modules) of the difference of arithmetic means between the statements are:

$$
\begin{gathered}
M_{\mathrm{S} 13}-M_{\mathrm{S} 14}=.63 \\
M_{\mathrm{S} 13}-M_{\mathrm{S} 15}=.60 \\
M_{\mathrm{S} 13}-M_{\mathrm{S} 16}=1.47
\end{gathered}
$$$$
\begin{gathered}
M_{\mathrm{S} 14}-M_{\mathrm{S} 15}=1.23 \\
M_{\mathrm{S} 14}-M_{\mathrm{S} 16}=2.10 \\
M_{\mathrm{S} 15}-M_{\mathrm{S} 16}=.87
\end{gathered}
$$

All absolute values (modules) of the arithmetic mean differences reach a critical difference, which means that they are all statistically significant.

Table 8. Correlation Matrix Set of Claims on the Socialization of Gifted Children

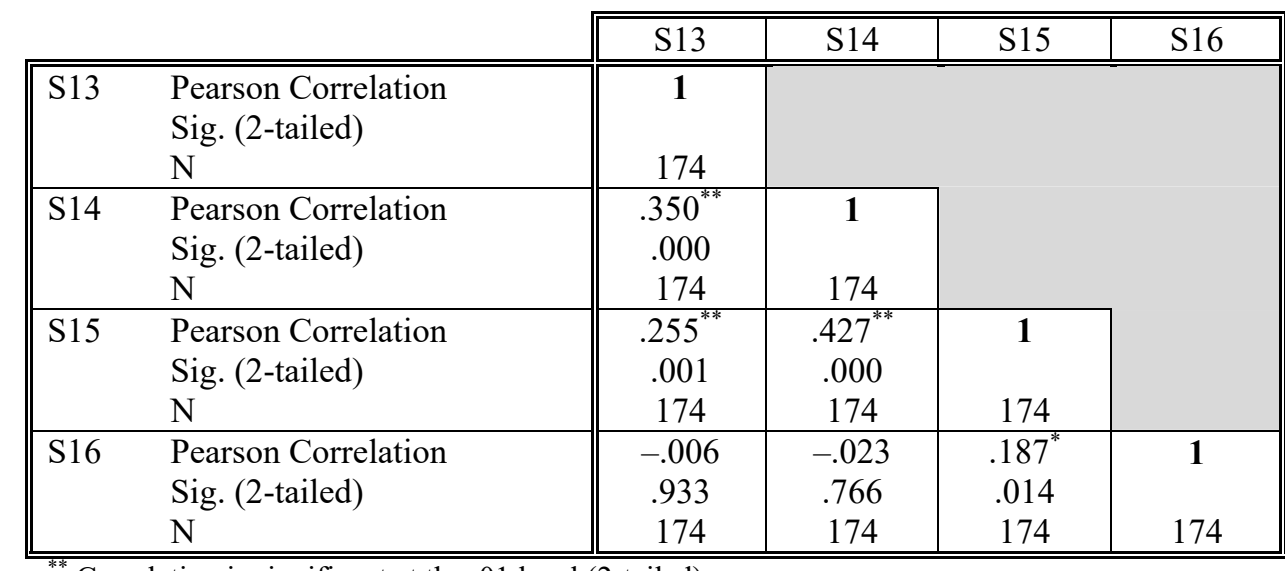

${ }_{* *}^{*}$ Correlation is significant at the .01 level (2-tailed)

* Correlation is significant at the .05 level (2-tailed).

Table 8 shows Pearson's correlation coefficients $r$, for the socialization assertions (claims) of gifted children. It can be observed that four relationships between the dependent variables are significant. This refers to the relationship between S13 and S14 where the correlation is $r=.350$, at the relationship between $\mathrm{S} 13$ and S15 where the correlation is $r=.255$, at the relationship between S14 and S15 where correlation $r=.427$ and at the relationship between S15 and S16, where the correlation coefficient is $r=.187$. The first three correlations are significant at the level .01, while the fourth correlation is significant at the level .05 .

In all four cases, there is a moderate and positive correlation. The remaining two correlation coefficients are not significant and both are of negative signs.

Since there was a small number of male respondents in the sample, only 3 or $1.7 \%$, the gender analysis was not performed. Therefore, we only dwell on the analysis of the respondents' responses with respect to their years of study. Using the analysis of variance, the results obtained are presented in Table $9(F$-values regarding the years of study of the respondents). As the cutoff value in the $F$-distribution at the significance level of $5 \%$ with $3 / 169$ degrees of freedom is $F=2.60$, the analysis of variance showed that the results of the respondents differ statistically significantly in as many as seven of the total sixteen response groups (in Table 9 these values are bolded).

Table 9. F-values regarding the study years of the subjects

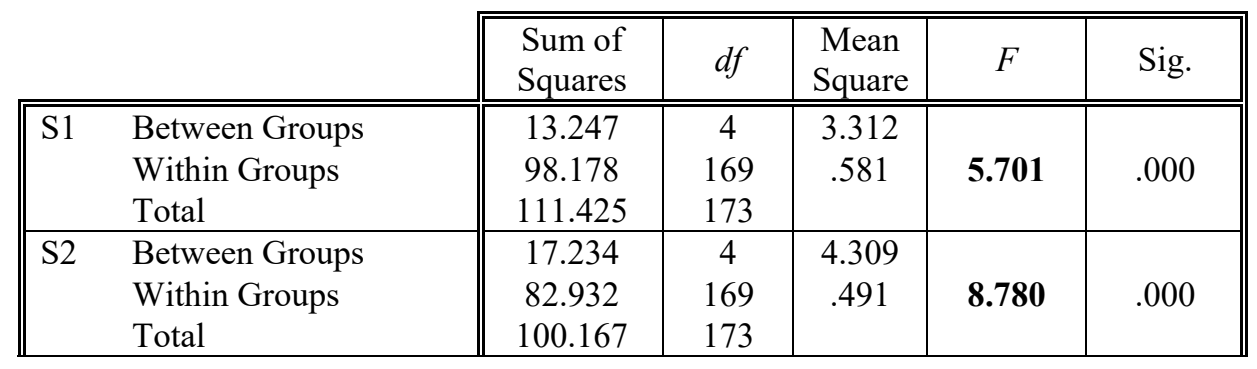




\begin{tabular}{|c|c|c|c|c|c|c|}
\hline S3 & $\begin{array}{l}\text { Between Groups } \\
\text { Within Groups } \\
\text { Total }\end{array}$ & $\begin{array}{c}3.968 \\
79.509 \\
83.477 \\
\end{array}$ & $\begin{array}{c}4 \\
169 \\
173 \\
\end{array}$ & $\begin{array}{l}.992 \\
.470\end{array}$ & 2.109 & .082 \\
\hline S4 & $\begin{array}{l}\text { Between Groups } \\
\text { Within Groups } \\
\text { Total }\end{array}$ & $\begin{array}{c}4.690 \\
68.603 \\
73.293\end{array}$ & $\begin{array}{c}4 \\
169 \\
173\end{array}$ & $\begin{array}{c}1.172 \\
.406\end{array}$ & 2.888 & .024 \\
\hline S5 & $\begin{array}{l}\text { Between Groups } \\
\text { Within Groups } \\
\text { Total }\end{array}$ & $\begin{array}{c}4.467 \\
122.889 \\
127.356 \\
\end{array}$ & $\begin{array}{c}4 \\
169 \\
173 \\
\end{array}$ & $\begin{array}{c}1.117 \\
.727\end{array}$ & 1.536 & 194 \\
\hline S6 & $\begin{array}{l}\text { Between Groups } \\
\text { Within Groups } \\
\text { Total }\end{array}$ & $\begin{array}{c}14.973 \\
151.492 \\
166.466\end{array}$ & $\begin{array}{c}4 \\
169 \\
173 \\
\end{array}$ & $\begin{array}{c}3.743 \\
.896\end{array}$ & 4.176 & .003 \\
\hline S7 & $\begin{array}{l}\text { Between Groups } \\
\text { Within Groups } \\
\text { Total }\end{array}$ & $\begin{array}{c}2.246 \\
165.713 \\
167.960 \\
\end{array}$ & $\begin{array}{c}4 \\
169 \\
173 \\
\end{array}$ & $\begin{array}{l}.562 \\
.981\end{array}$ & .573 & .683 \\
\hline S8 & $\begin{array}{l}\text { Between Groups } \\
\text { Within Groups } \\
\text { Total }\end{array}$ & $\begin{array}{c}9.248 \\
139.442 \\
148.690 \\
\end{array}$ & $\begin{array}{c}4 \\
169 \\
173 \\
\end{array}$ & $\begin{array}{c}2.312 \\
.825\end{array}$ & 2.802 & .028 \\
\hline S9 & $\begin{array}{l}\text { Between Groups } \\
\text { Within Groups } \\
\text { Total }\end{array}$ & $\begin{array}{c}9.335 \\
177.797 \\
187.132 \\
\end{array}$ & $\begin{array}{c}4 \\
169 \\
173 \\
\end{array}$ & $\begin{array}{l}2.334 \\
1.052\end{array}$ & 2.218 & .069 \\
\hline S10 & $\begin{array}{l}\text { Between Groups } \\
\text { Within Groups } \\
\text { Total }\end{array}$ & $\begin{array}{c}1.869 \\
209.579 \\
211.448\end{array}$ & $\begin{array}{c}4 \\
169 \\
173 \\
\end{array}$ & $\begin{array}{c}.467 \\
1.240\end{array}$ & .377 & .825 \\
\hline S11 & $\begin{array}{l}\text { Between Groups } \\
\text { Within Groups } \\
\text { Total }\end{array}$ & $\begin{array}{c}5.449 \\
189.424 \\
194.874 \\
\end{array}$ & $\begin{array}{c}4 \\
169 \\
173 \\
\end{array}$ & $\begin{array}{l}1.362 \\
1.121\end{array}$ & 1.215 & .306 \\
\hline S12 & $\begin{array}{l}\text { Between Groups } \\
\text { Within Groups } \\
\text { Total }\end{array}$ & \begin{tabular}{|l}
42.584 \\
222.341 \\
264.925 \\
\end{tabular} & $\begin{array}{c}4 \\
169 \\
173 \\
\end{array}$ & $\begin{array}{c}10.646 \\
1.316\end{array}$ & 8.092 & .000 \\
\hline $\mathrm{S} 13$ & $\begin{array}{l}\text { Between Groups } \\
\text { Within Groups } \\
\text { Total }\end{array}$ & $\begin{array}{c}7.241 \\
172.460 \\
179.701 \\
\end{array}$ & $\begin{array}{c}4 \\
169 \\
173 \\
\end{array}$ & $\begin{array}{l}1.810 \\
1.020\end{array}$ & 1.774 & .136 \\
\hline S14 & $\begin{array}{l}\text { Between Groups } \\
\text { Within Groups } \\
\text { Total }\end{array}$ & $\begin{array}{c}544 \\
174.819 \\
175.362 \\
\end{array}$ & $\begin{array}{c}4 \\
169 \\
173 \\
\end{array}$ & $\begin{array}{l}.136 \\
1.034\end{array}$ & .131 & .971 \\
\hline S15 & $\begin{array}{l}\text { Between Groups } \\
\text { Within Groups } \\
\text { Total }\end{array}$ & $\begin{array}{c}14.910 \\
156.567 \\
171.477\end{array}$ & $\begin{array}{c}4 \\
169 \\
173\end{array}$ & $\begin{array}{c}3.727 \\
.926\end{array}$ & 4.023 & .004 \\
\hline S16 & $\begin{array}{l}\text { Between Groups } \\
\text { Within Groups } \\
\text { Total }\end{array}$ & $\begin{array}{c}3.403 \\
98.505 \\
101.908 \\
\end{array}$ & $\begin{array}{c}4 \\
169 \\
173 \\
\end{array}$ & $\begin{array}{l}.851 \\
.583\end{array}$ & 1.459 & .217 \\
\hline
\end{tabular}

The stated statistical significance of the differences with respect to the years of study of the respondents relate to the following statements: "Upon completion of the studies, I will be able (competent) to identify, i.e. for recognizing a gifted child $(\mathrm{F}=5,701)$; Upon completion of my studies, I will be able (competent) to work with gifted children $(\mathrm{F}=8,780)$; Teachers of methodologies have to instruct students to work with gifted children $(\mathrm{F}=2,888)$; It is much more challenging to prepare activities for working with a gifted child $(\mathrm{F}=4.176)$; As a future educator, I will keep special notes on gifted children $(F=2,802)$; Gifted children are loved by other children in the group $(\mathrm{F}=8,092)$; the gifted child is bored by the classical activities in the kindergarten $(\mathrm{F}=4.023)$ ". The remaining nine $F$-values are less than the cut-off value, and accordingly the respondents' answers are not statistically significant.

\section{Conclusion}

Researches to this moment confirm that identifying gifted individuals and adequately working with them is a prerequisite for developing their potential from an early age. This implies the professional capability and professional competence of professional staff in pre-school institutions for working with these children. Bearing in mind the characteristics and regularities of the development of preschool children, with this research we wanted to examine the thoughts and attitudes of students, future educators in preschool institutions, about the potential giftedness of preschool children and working with them. This goal has been specified through research tasks related to: a) the quality of the educators' professional 
competence to work with gifted children; b) teachers' interest in working with these children; c) the relationship of gifted children with other children in kindergarten groups; and d) socialization of gifted children of preschool age.

The results of the survey of a sample of students, future educators in pre-school institutions, confirm that they believe that they are sufficiently and well prepared during their studies to work with gifted children. In their kindergarten groups, they would like to have gifted individuals and work with them. During their studies, through organized practice in pre-school institutions, they got the impression that the relationship between gifted and other kindergarten children is harmonious, and they consider that gifted children should not be separated into special kindergarten groups. Also, they have the attitude that gifted children do not have any difficulties in socialization. With good organization of activities, they are not bored in such an environment.

Such attitudes of the surveyed students suggest that the program contents of university education (future preschool teachers-educators) are concretized in relation to identification and work with gifted children, with the need to plan and organize activities in preschool institutions, taking into account the potential of gifted children. Also, the issue of segregation as a form of work for preschool-age children is raised for the researchers of this problem and for professional workers in preschool institutions.

We believe that the results of this research can provide a good starting point for researchers to further address the issues of continuing professional and methodological training of educators to organize activities in which they will encourage children to display their creativity and potential talent.

\section{References}

[1]. Kukanja Gabrijelčič, M. \& Gorela, K. (2018). Nadarjenost na predškolskoj stopnji. Koper: Založba Univerze na Primorskem. Retrieved from: https://www.hippocampus.si/ISBN/978-961-7055-252.pdf [accessed: 10 May 2021].

[2]. Vukosav, J., \& Sindik, J. (2010). Povezanost dimenzija tri mjerna instrumenta za procjenu darovitosti i neverbalne inteligencije predškolske djece. Metodički ogledi: časopis za filozofiju odgoja, 17(1-2), 149-175.

[3]. Kukanja Gabrijelčič, M. (2016). Subjektivne teorije in težave vzgojitelja pri delu $\mathrm{z}$ nadarjenim otrokom. Slavonic Pedagogical Journal, 5(1), 86-100.

[4]. Bodriĉ, R. (2009). Daroviti, nacionalni potencijal znanja-nacionalna briga. Daroviti $i$ društvena elita, 92-99.
[5]. Kadum, S., \& Hozjan, D. (2015). Darovitost $u$ nastavi. Sveučilište Jurja Dobrile u Puli.

[6]. Crljen, M., \& Polić, R. (2006). Briga za nadarenu djecu. Metodički ogledi: časopis za filozofiju odgoja, 13(1), 137-147.

[7]. Zloković, J. (2016). Poticanje razvoja darovite dece i učenika - obiteljski i socijalni kapital. Suvremeni pristup odgoju i obrazovanju darovite djece i učenika, 41-52. Zadar: Odjel za izobrazbu učitelja i odgojitelja.

[8]. Bouillet, D. (2011). Kompetencije odgojitelja djece rane i predškolske dobi za inkluzivnu praksu. Pedagogijska istraživanja, 8(2), 323-338.

[9]. Milovanović, R., \& Kopas-Vukašinović, E. (2014). Percepcije kreativnosti i kreativni potencijali budućih vaspitača i učitelja. Zbornik Instituta za pedagoška istraživanja, 46(1), 181-199.

[10]. Hodge, K. A., \& Kemp, C. R. (2006). Recognition of giftedness in the early years of school: Perspectives of teachers, parents, and children. Journal for the Education of the Gifted, 30(2), 164-204.

[11]. Pfeiffer, S. I., \& Petscher, Y. (2008). Identifying young gifted children using the gifted rating scalesPreschool/kindergarten form. Gifted Child Quarterly, 52(1), 19-29.

[12]. Renzulli, J. S., Siegle, D., Reis, S. M., Gavin, M. K., $\&$ Reed, R. E. S. (2009). An investigation of the reliability and factor structure of four new scales for rating the behavioral characteristics of superior students. Journal of Advanced Academics, 21(1), 84108.

[13]. Apostolović, D. (2016). Kurikulumi predškolskog vaspitanja kao osnova za planiranje i programiranje rada vaspitača u predškolskoj ustanovi. Savremeno predškolsko vaspitanje $i$ obrazovanje-izazovi $i$ dileme', Jagodina, 297-313.

[14]. Nikčević-Milković, A., Jerković, A., \& Rukavina, M. (2016). Stanje, problemi i potrebe rada s darovitim učenicima u osnovnim školama u Republici Hrvatskoj. Magistra Iadertina, 11(1), 9-34.

[15]. Bedeković, V., Jurčić, M., Kolak, A. (2009) Sociometrijski status darovitog učenika $i$ njegov položaj u društvenoj (razrednoj) eliti. U: Gojkov, Grozdanka (ur.) Daroviti i društvena elita. Vršac: Visoka škola strukovnih studija Vršac.

[16]. Ivon, H., \& Sindik, J. (2008). Povezanost empatije i mašte odgojitelja s nekim karakteristikama ponašanja i igre predškolskog djeteta. Magistra iadertina, 3(1), 21-38.

[17]. Kubelka R., Pelt R., Vrbanac D. (2013) “Dječji talenti - Otkrijte talente svojeg djeteta podržavajući izvornost dječjeg učenja", Velika Mlaka, Ostvarenje.

[18]. Kopas-Vukašinović, E. \& Jovanović, V. (2012). Govorne aktivnosti predškolske dece u funkciji razvoja njihovih kreativnih potencijala. Nastava $i$ vaspitanje, 61(2), 266-279.

[19]. Grandić, R., \& Letić, M. (2009). Stanje, problemi i potrebe $\mathrm{u}$ području brige o darovitim učenicima $\mathrm{u}$ našem obrazovnom sistemu. Originalan znanstveni rad, 232-243.

[20]. Paser, V. \& Božin, A. (2009). Daroviti kao potencijalna elita. Daroviti $i$ društvena elita 15, 415424. Vršac: Visoka škola strukovnih studija za obrazovanje vaspitača „Mihailo Palov”. 